\title{
EDITORIAL
}

\section{A Tribute to Kurt Stange and the First Seventeen Years}

\author{
Jobn J. Frey III, MD, Associate Editor \\ Ann Fam Med 2019;17:290. https://doi.org/10.1370/afm.2434.
}

W ith this issue, we welcome Caroline R. Richardson, $\mathrm{MD}$ as the new editor in chief of Annals of Family Medicine. Our sincere thanks to Bill Phillips, who served as editor from January to June of this year, following Kurt Stange's 17-year term as inaugural editor. As the journal begins a new chapter, we look back on its history and the legacy that Kurt and his team leave behind.

In 2002, six North American family medicine organizations (later joined by a seventh) decided to design and sponsor a new research-focused journal. Through their efforts, the Annals of Family Medicine came into being. But starting a new journal was a gamble; many academic organizations questioned whether a sufficiently robust investigator constituency and readership existed in a discipline that did not have a long history of well-funded research. And, while editor/publisher relationships can be managed with tact and time, having six sponsors was daunting.

Kurt Stange, MD, PhD became the founding editor and, in his team's first editorial about the direction for the Annals, used the term stewardship to characterize his view of an editor. ${ }^{1}$ From his wide-ranging contacts across the discipline, he assembled a team of editors and staff over the next seventeen years, growing the Annals to a level of international preeminence in family medicine. Over those years, Dr Stange has engaged authors, reviewers, and readers with a personal sensibility that guided the journal: breadth and depth, theory and experiment, practice and research, topical and historical. His success as an editor in great part came from his eagerness to explore ideas that offered to bring new insights into primary care from social sciences, health services research, memorable and important essays, widely cited methods articles, authoritative editorials and commentaries, and randomized controlled trials of everything from practice redesign to meditation and exercise. Under Dr Stange's leadership, the Annals has published important research from countries all over the world. At the urging of the World Organization of National Colleges, Academies and Academic Associations of General Practitioners/ Family Physicians (WONCA), the National Library of Medicine and Web of Science each added a new journal category called Primary Health Care. Since then, the Annals of Family Medicine has consistently ranked first worldwide among primary health care journals in Clarivate Analytics' (previously Thomson Reuters') Journal Citation Reports. ${ }^{2}$

Perhaps most importantly, Dr Stange has created networks of colleagues throughout medicine and public policy and has served as a mentor and coach for editors and journals in many other countries. His generosity and genuinely collaborative spirit permeated the operation of the Annals. As an editor, he listened to differing points of view and his recommendations about publishing decisions generally summarized how the group processed those differences. He has taken his responsibility as a shaper of thought in family medicine seriously and has served as a bridge builder and guide who, through his editorials, showed respect for history as well as a sense of urgency about the future.

A number of perspectives characterize Kurt Stange's philosophy, a philosophy that came through in his leadership of the Annals as well as his continuing work as a teacher, scientist, and writer: we always work better in teams, we are both foresters and arborists, and we can be both artists and scientists.

To read or post commentaries in response to this article, see it online at http://www.AnnFamMed.org/content/17/4/290.

\section{References}

1. Stange KC, Phillips WR, Acheson LS, Crabtree BF, Zyzanski SJ, Miller WL, Gotler RS. Welcome to the Annals of Family Medicine. Ann Fam Med. 2003;1(1):2-4. doi:10.1370/afm.46.

2. Scijournal.org. Impact Factor List (website). Annals of Family Medicine impact factor. https://www.scijournal.org/impact-factor-of-ANNFAM-MED.shtml. Accessed Jun 19,2019. 